\title{
Open access and health librarians in 2011
}

\author{
Devon Greyson
}

\begin{abstract}
This paper provides an overview of the open access (OA) movement to date, with specific focus on both health information and Canada, updates on some major areas of OA activity, and a discussion of emerging opportunities and needs for librarians due to the evolving OA paradigm.
\end{abstract}

\section{Open access and health librarians in 2011}

The area of open access (OA) to scholarly communications and health information has grown and developed much in recent years. Here in 2011, we sit a full 14 years since PubMed's "experimental search system" became freely available online; 9 years after the Budapest Open Access Initiative called for the opening up of scholarly literature; and 3 years after the implementation of an OA policy for peer-reviewed research funded by the Canadian Institutes of Health Research / Instituts de recherche en santé du Canada (CIHR / IRSC). Health information has emerged as "ground zero" of the OA movement in Canada and beyond, and health information specialists are increasingly called upon to advise and facilitate open scholarly communications.

Yet such strides toward freely available information have not come without resistance and backlash. Fear and misinformation regarding change within the scholarly publishing industry remain widespread, and business models supporting OA journals are often still experimental. While the potential for universal access to online information is great, the transition does carry risks for some stakeholders and confusion for many. Librarians, sometimes in new roles and under different job titles, are well poised to offer support for this transition to a more open era.

This paper provides an overview of the OA movement to date, with specific focus on both health information and Canada, updates on some major areas of OA activity, and a discussion of emerging opportunities and needs for librarians due to the evolving OA paradigm.

\section{A brief history of open access}

Tracing the development of OA, one must look back at least as far as the emergence of e-journals in the late 1980s (a more thorough history might trace the movement back to the 1960s and the United States Department of Defense's development of Internet-predecessor ARPANET). Publishers of early e-journals included Stevan Harnad (Psycoloquy, 1989), Charles W. Bailey (Public Access Computer Systems
Review, 1989), and Jean-Claude Guédon (Surfaces, 1991); all prominent $\mathrm{OA}$ advocates to this day.

The 1990s brought about the first declarations of free access to information, including the 1991 "Bromley Principles" regarding full and open access to "global change" data [1], and the 1996 Bermuda Principles, which suggested that all human genomic sequence information be entered into the public domain, and was adopted as policy for the Human Genome Project [2]. The year 1994 marked a turning point in public use of the Internet, largely due to the mass uptake of Mosaic/Netscape's graphical browsers. With the dramatic increase in Internet use, e-journals and policy regarding freely available online information proliferated. In 1997, the United States National Library of Medicine announced free web-based access to MEDLINE via PubMed [3], making a dramatic mark on the health information world.

The early 2000s brought the major OA declarations: Budapest [4], Bethesda [5], and Berlin [6], which collectively established a working definition of OA. At the same time, a genre of research literature seeking to quantify impact advantages or disadvantages of OA was emerging [7-9]. Following on the heels of these developments, library associations began to adopt policy statements on OA, including the Medical Library Association in 2003 [10], International Federation of Library Associations and Institutions (IFLA) in 2004 [11], the British Columbia Library Association also in 2004 [12], and the Canadian Library Association in 2005 (revised in 2008) [13].

While some differences persist, at this point there is a fairly strong consensus around core elements of a definition of OA. These elements generally echo Peter Suber's basic definition [14], namely that OA literature is (a) free to read, (b) online, and (c) often subject to more permissive copyright and licensing restrictions than traditionally published literature. Works that are OA can be either "gold" (the published version of record is openly accessible), "green" (the published version of record is behind a paywall, but a copy has been openly archived online), or both. Today, OA is generally, albeit not exclusively, used to refer to scholarly literature, particularly peer-reviewed journal articles.

Today, OA seems an unstoppable movement. The Directory of Open Access Journals [15] contains over 6000

D. Greyson. University of British Columbia Centre for Health Services and Policy Research, 201-2206 East Mall, Vancouver, British Columbia, Canada V6T 1Z3, (e-mail: dgreyson@chspr.ubc.ca). 
journals, with estimates on the proportion of peer-reviewed journals that are OA coming in at around $20 \%$ overall, and higher in biomedicine [16]. Several OA journals have rocketed to prominence in the Impact Factor rankings, spawning copycat journals across publishers. Journal publishers, while often continuing to experiment with business models as well as access models, are increasingly demonstrating awareness of research funder mandates [17] and an understanding that, at least as part of their portfolio, OA is here to stay [18]. Institutional repositories are becoming standard equipment for universities, and subject repositories such as PubMed Central and E-LIS continue to grow, along with OA mandates from research funders and academic institutions.

The Canadian Health Libraries Association / Association des bibliothèques de la santé du Canada (CHLA / ABSC) has a record of support for OA that includes publishing activities, policy advocacy, and member education resources. Starting in 2004, CHLA / ABSC hosted conference sessions [19], published articles in the Journal of the Canadian Health Libraries Association / Journal de l'Association des bibliothèques de la santé du Canada (JCHLA / JABSC) discussing [20] and investigating [21] OA and related topics, and provided Fact Sheets on OA related issues [22]. CHLA / ABSC converted this journal to gold OA in May 2006, and has been digitizing prior issues over the past few years. Also in 2006, CHLA / ABSC submitted a response to the CIHR / IRSC draft policy on access to research outputs, speaking in favour of a strong OA policy by the funder. In 2010, CHLA / ABSC approved an Open Access Interest Group [23], open to all members in good standing, for the purpose of supporting discussion, education, and advocacy related to $\mathrm{OA}$ and related scholarly communications issues.

\section{Entwinement of open access and health}

While biomedicine was not among the very first fields to adopt OA archiving or publishing practices, health has been entwined with OA since the topic entered the public policy arena. This is due to both characteristics of the medical publishing industry and characteristics of health as a field of research and practice. Similar to other access issues within medicine, communication of health-relevant information carries an element of moral imperative. Evidence-based medicine relies on care providers having access to current scientific information. Subscription cost barriers create disparities between "have" and "have-not" practitioners, regions, and countries. Globally, those in poorer or "developing" countries can rarely afford journal subscriptions akin to those enjoyed by Canadians, and even within our national boundaries there are substantial differences in access among health practitioners.

The consumer health movement has encouraged the development of "activated" patients who desire public access to the scientific literature in order to participate in their own health care. In an era of increased advertising of health products, such as prescription drugs, to both health professionals and the public, there is a call for access to the scientific literature in order to counteract any bias present in advertisements. Additionally, a large amount of health research is publicly-funded, fuelling a sentiment of public entitlement to the results of government-funded research. Evidence-based medicine, global health and the digital divide, the consumer health movement, concerns about advertising of health products, and calls for government accountability all contribute toward a climate in which OA to scientific health information holds moral appeal.

Issues of prestige, journal funding sources and conflict of interest in medical publishing have also contributed to the OA focus on health. The prestige and impact of medical journals varies widely. The most prominent journals are for many researchers the place to publish in order to make a name for oneself. With prestige has often come cost, and subscriptions to top-tier journals can be very expensive, with specialised niche journals in certain fields being even more costly. Medical publishing has historically relied on a variety of revenue streams, including subscriptions, advertising, sponsorship, reprint charges, and in some subfields author charges. Because article reprints may be used by drug and device makers as part of promotional activities, this revenue stream is more significant in medical publishing than in many other fields.

While the issue of conflicts of interest (COI) in medical publishing is a separate one from that of OA, due to some high-profile events they have become associated. In 1999 , when JAMA editor George Lundberg was fired over his decision to publish an article concluding that the majority of college students did not believe oral sex was "having sex" while the U.S. Senate was holding President Clinton's impeachment hearings [24], he became editor in chief of online medical information portal Medscape. Later that same year, NEJM fired editor Jerome Kassirer over his refusal to allow the use of the NEJM name, logo and reputation to create new revenue streams out of articles rejected by NEJM [25]. In 2006, the CMAJ fired top editors John Hoey and Anne Marie Todkill over editorial differences that came to a head over an article regarding the controversial over-the-counter status of the "morning after pill" Plan B, inspiring a mass flight from the CMAJ editorial board. These editors turned around to found OA journal Open Medicine the following year. While these editorial disputes were not specifically about free public access to research, and OA itself is not necessarily an answer to COI issues, the fact that the casualties of editorial skirmishes have become proponents of free online health literature has created entanglement between the issues of OA and transparency in medical publishing.

It should be noted that not everyone is wholly in favour of OA to health literature. With concerns about the quality of peer-review, journal editing and measures of publication impact already abundant within traditional scientific literature, any challenges to the publishing industry status quo raise fears about the future of scholarly publishing. Some argue that while free access is merited within lowincome countries, publishers should continue to charge for access in wealthy countries. A few voices have expressed concern about the general public's ability to interpret medical research intended for an expert audience, fearing that releasing medical literature into the wilds might cause unnecessary fear and misunderstanding among patients.

\section{Canada and OA to health information}

In the international forum, Canada has shown leadership in some areas of OA, and lagged behind the pack in others. 
An area of significant leadership has been research funder action, including mandates on free access to results of funded research, especially in health. As of the time of writing, Canada has 11 researcher funder mandates listed in the Sherpa Project's Juliet database [26], 9 of which are specifically biomedical or health funders. The CIHR / IRSC have shown great leadership in this area, mandating researchers to attempt to achieve free online access to all peer-reviewed articles resulting from funded research as of January 2008, and allowing only a 6-month embargo period - standards that have been emulated by many other Canadian funders. The CIHR / IRSC worked with Canadian Institute for Scientifuc and Technical Information (CISTI) and the United States National Library of Medicine to develop and launch PubMed Central Canada, the first bilingual PubMed Central portal and mirror site. CIHR / IRSC has also provided 3-year funding for CHLA / ABSC's Canadian Virtual Health Library (CVHL) project [27]. Another area in which Canadian OA efforts have met with success is the development of university institutional repositories (IRs). Thanks in large part to the library sector and the CARL IR Program [28], IRs have become nearly ubiquitous in Canadian universities, leaving few academic researchers wanting for a place to securely archive their work.

In contrast to the leadership shown by our research funders and academic libraries, Canada's university administrations and government policy have been slower to take initiative on OA. University research administrators aware of $\mathrm{OA}$, but are only beginning to explore ways to respond to research funder OA policies and assist affiliated researchers with policy compliance [29]. While institutional repositories are widespread, according to the MELIBIA database [30] Canada now has just 8 university OA policies, half of which are university-wide and half of which were adopted by a specific school or faculty within a university. Unlike the pattern in some other countries (e.g., the US and UK), university OA policy adoption in Canada has not been led by the largest and most prominent universities, nor is there a major national multi-university OA implementation group.

Similarly, Canada lacks a national stance or platform on $\mathrm{OA}$ as well as other key elements of a national digital strategy. Certain branches of the government - for example Library and Archives Canada - are embracing "going digital" [31] in order to provide increased public access. However, despite new calls from the Conference Board of Canada to open up publicly funded research [32], the idea of a national OA requirement hasn't gained much support from legislators. Canadian research funder policies, while a strength, do not always carry much influence with publishers who are primarily oriented toward the larger US National Institutes of Health access policy with different archiving standards, and this works against the success of PubMed Central Canada and compliance with our funder policies. Greater advocacy with publishers and a stronger, more unified Canadian voice are needed to ensure that our university and research funder OA policies are respected internationally.

\section{Opportunities for health librarians}

The emergent era of open scholarly communications creates opportunities for health librarians. We may increasingly be called upon to collaborate in research and take on some OA-related new roles. We have seen new job titles, such as "scholarly communications librarian" and a proliferation of digital initiative management jobs, particularly within academic library settings. In the publishing world, librarians are marketable and desirable copyright consultants, publishers and journal editorial board members. Many librarians with records management skill sets may act as preservationists of research and data, creating and managing open digital repositories, policies and archives.

The growing ocean of openly available information requires new forms of media navigation and literacy instruction to faculty, students, health care providers and the public - instruction that librarians are highly qualified to offer as an evolution of traditional bibliographic instruction methods. Within the research domain, librarians are already heavily involved in tracking the growth of OA [33], investigating the relationship between $\mathrm{OA}$ and publication impact [34], and examining the social, political and behavioural aspects of OA adoption and resistance $[29,35,36]$.

The spread of the "open" movement into government and researcher data [37,38], as well as the potential for widespread adoption of open notebook science [39] and open educational resources [40,41], create yet more opportunities for health librarians and other information specialists. Many of these opportunities may look suspiciously like our old roles, as they rely on applying skills and tools of traditional librarianship to the new landscape of openly accessible digital media. The world of OA today is vastly different that of just a few years ago, and can be expected to continue rapid evolution in the near future. Within this world are a multitude of new opportunities for health librarian leadership, should we rise to the challenge, adapting our strengths to meet these emerging needs.

\section{References}

1. Bromley A. Policy Statements on Data Management for Global Change Research [Internet]. Washington, D.C.: U.S. Global Change Research Program; 1991 Jul 2 [cited 2010 Nov 19]. Available from: http://www.gcrio.org/USGCRP/DataPolicy. html

2. Bermuda Sequence Policies [Internet]. Washington, D.C.: U.S. Department of Energy Genome Programs; 1997 Mar 2 [cited 2011 Mar 14]. Available from: http://www.ornl.gov/sci/ techresources/Human_Genome/research/bermuda.shtml

3. U.S. National Library of Medicine. Free Web-Based Access to NLM Databases. NLM Technical Bulletin. May-Jun 1997 [Internet]. [cited 2011 Mar 14]. Available from: http://www. nlm.nih.gov/pubs/techbull/mj97/mj97_web.html

4. Chan L, Cuplinskas D, Eisen M, et al. Budapest Open Access Initiative [Internet]. Open Society Institute; 2002 Feb 14 [cited 2011 Mar 14]. Available from: http://www.soros.org/openaccess/ read.shtml

5. Bethesda Statement on Open Access Publishing [Internet]. Chevy Chase, MD; 2003 April 11 [cited 2011 Mar 14]. Available from: http://www.earlham.edu/\%7Epeters/fos/ bethesda.htm 
6. Berlin Declaration on Open Access to Knowledge in the Sciences and Humanities [Internet]. 2003 Oct 22 [cited 2011 Mar 14]. Available from: http://oa.mpg.de/lang/en-uk/berlinprozess/berliner-erklarung/

7. Anderson K, Sack J, Krauss L, O'Keefe L. Publishing OnlineOnly Peer-Reviewed Biomedical Literature: Three Years of Citation, Author Perception, and Usage Experience. The Journal of Electronic Publishing. 2001; 6(3): 06-03. doi:10. 3998/3336451.0006.303

8. Lawrence S. Online or Invisible? Nature. 2001;411:521.

9. Antelman K. Do open-access articles have a greater research impact. Coll Res Libr. 2004; 65(5):372-382.

10. Medical Library Association. MLA Statement on Open Access [Internet]. 2003 Oct [cited 2011 Mar 14]. Available from: http:// www.mlanet.org/government/info_access/openaccess_statement. html

11. International Federation of Library Associations and Institutions. IFLA Statement on Open Access to Scholarly Literature and Research Documentation [Internet]. 2003 Jul [cited 2011 Mar 14]. Available from: http://archive.ifla.org/V/cdoc/ open-access04.html

12. British Columbia Library Association. A Resolution on Open Access [Internet]. 2004 Jun 19. Available from: http://www. bcla.bc.ca/IPC/Resolutions/2004-openaccess-passed.pdf

13. Canadian Library Association / Association canadienne des bibliothèques. Canadian Library Association / Association canadienne des bibliothèques Position Statement on Open Access for Canadian Libraries [Internet]. 2008 May 21 [cited 2011 Mar 14]. Available from: http://www.cla.ca/AM/ Template.cfm?Section=Position_Statements\&Template $=/ \mathrm{CM} /$ ContentDisplay.cfm\&ContentID $=5306$

14. Suber P. Open Access Overview (definition, introduction) [Internet]. 2007 Jun 19. Available from: http://www. earlham.edu/ peters/fos/overview.htm

15. Directory of open access journals [Internet]. Lund, Sweden: Lund University Libraries; 2011 [cited 2011 Mar 21]. Available from: http://www.doaj.org/

16. Björk B-C, Welling P, Laakso M, Majlender P, Hedlund T, Guðnason G. Open Access to the Scientific Journal Literature: Situation 2009. PLoS ONE. 2010 Jun 23;5(6):e11273. doi:10.1371/journal.pone.0011273

17. Nature Publishing Group. NPG position statement on open access publishing and subscription business models. [Internet]. 2011 Jan 6 [cited 2011 Mar 11]. Available from: http:// www.nature.com/press_releases/statement.html

18. Springer. Springer Acquires BioMed Central Group [Internet]. 2008 [cited 2011 Mar 11]. Available from: http://www.springer. com/authors/author+zone?SGWID=0-168002-12-563100-0

19. Canadian Health Libraries Association. Abstracts from the CHLA / ABSC 2004 Conference - On the Edge. J Can Health Libr Assoc. 2004 Sept;25(3):61-67.

20. Morrison H, Waller A. Open access for the medical librarian. J Can Health Libr Assoc. 2006 Sep;27(3):69-73.

-21. Greyson D, Morgan S, Hanley G, Wahyuni D. Open access archiving and article citations within health services and policy research. J Can Health Libr Assoc. 2009 Jun;30(2):51-58.
22. CHLA-ABSC. Fact Sheets [Internet]. 2008 [cited 2011 Mar 14]; Available from: http://www.chla-absc.ca/node/689

23. CHLA-ABSC. Open Access Interest Group [Internet]. 2010 [cited 2011 Mar 14]; Available from: http://www.chla-absc.ca/ node/635

24. Elmsie T, Flegel K, Joseph K, et al. Science, sex and semantics: the firing of George Lundberg. CMAJ. 1999 Feb 23;160(4): 507-8.

25. Hoey J. When journals are branded, editors get burnt: the ousting of Jerome Kassirer from the New England Journal of Medicine. CMAJ. 1999 Sep 7;161(5):529-530.

26. SHERPA. SHERPA - JULIET - Research funders' open access policies [Internet]. Available from: http://www. sherpa.ac.uk/juliet/index.php

27. Canadian Virtual Health Library [Internet]. Toronto, ON: CHLA/ABSC; 2011 Mar 24 [cited 2011 April 4]. Available from: http://chla-absc.ca/nnlh/cvhl/

28. CARL/ABRC. The CARL Institutional Repositories Program: Vision, Priorities, and Projects [Internet]. Ottawa, ON: Canadian Association of Research Libraries. [cited 2011 Mar 14]. Available from: http://www.carl-abrc.ca/ projects/institutional_repositories/member_resources-e.html

29. Greyson D, Vézina K, Taylor D, Morrison H, Black C. 2009; University supports for open access: A Canadian national survey. Can J Higher Ed. 2009; 39(3): 1-32.

30. Rodriguez Gairin, JM. MELIBEA [Internet]. Grupo of investigación "Acceso abierto a la ciencia"; 2010 Dec 3 [cited 2011 Mar 14]. Available from: http://www.accesoabierto.net/ politicas/

31. Government of Canada. Library and Archives goes digital: Library and Archives Canada Announces Suite of Digital Services for Canadians by 2017 [Internet]. Ottawa, ON; 2010 Dec 7 [cited 2011 Mar 11]. Available from: http:// www.collectionscanada.gc.ca/whats-new/013-503-e.html

32. Corbin RM. Intellectual Property in the 21st Century [Internet]. Conference Board of Canada; 2010 [cited 2011 Mar 14]. Available from: http://www.conferenceboard.ca/documents. aspx?did $=3452$

33. Morrison H. Dramatic growth of open access (series) [Internet]. The Imaginary Journal of Poetic Economics. ongoing [cited 2011 Mar 21]. Available from: http://poeticeconomics.blogspot.com/ search/label/dramatic $\% 20$ growth $\% 20$ of $\% 20$ open $\% 20$ access

34. Hitchcock S. The effect of open access and downloads ('hits') on citation impact: a bibliography of studies [Internet]. 2011 [cited 2011 Mar 21]. Available from: http://opcit.eprints.org/ oacitation-biblio.html

35. Dill EA, Palmer KL. Survey of Librarian Attitudes About Open Access. 2007 Jul 17 [cited 2011 Mar 21]. Available from: http://hdl.handle.net/1805/1113

36. Morrison H, Owen B, Taylor D, Waller A, Vézina K. Open Access Journals Support in Canada. 2010 June [cited 2011 Mar 21]. Available from: http://eprints.rclis.org/handle/ 10760/14671

37. Datadotgc.ca: A citizen-led beta for government data [Internet]. 2011 [cited 2011 Mar 21]. Available from: http://www. datadotgc.ca/ 
38. Government of Canada. Research Data Strategy [Internet]. Ottawa, ON: Government of Canada; 2011 [cited 2011 Mar 21]. Available from: http://rds-sdr.cisti-icist.nrc-cnrc.gc.ca/ eng/index.html

39. OpenWetWare [Internet]. 2009 [cited 2011 Mar 21]. Available from: http://openwetware.org/wiki/Main_Page
40. OER Commons [Internet]. Half Moon Bay, CA: Institute for the Study of Knowledge Management in Education (ISKME); 2007. [cited 2011 Mar 21]. Available from: http://www.oercommons.org/

41. Open Courseware Consortium. OCW Consortium [Internet]. Cambridge, MA: OpenCourseWare Consortium [cited 2011 Mar 21]. Available from: http://www.ocwconsortium.org/ 
This article has been cited by:

1.2011. Full issue in PDF / Numéro complet en form PDF. Journal of the Canadian Health Libraries Association 32:3, 133-184. [Citation] [PDF] [PDF Plus]

2. Gordon Shannon. 2011. Why libraries aren't dead: open access and the evolving liaison role. Journal of the Canadian Health Libraries Association 32:3, 165-167. [Abstract] [Full Text] [PDF] [PDF Plus] 